\title{
Development of Service-Learning Integrated in Civics Education for a Better Earth-A Contribution of Social Study
}

\author{
Juliana Tirza \\ Civics Education \\ Pelita Harapan University \\ Indonesia \\ mj.tirza@gmail.com
}

\begin{abstract}
The educational society for a long time has been trapped in the stigma that environmental problems are the responsibility of natural science. Using qualitative data, I found that service-learning integrated to social studies especially civics education was able to contribute to the improvement of our environment today and be a media for self-existence for students who are the agent of transformation to reveal a sustainable environment. Tried to make a difference, I tried to focus on designing service-learning according to our culture and explored more about the significance of service-learning as a media for the existence of students who are agents of transformation in discussing environmental sustainability issues. I conclude by discussing the potential for developing service learning in civic education which is prioritized for future research and applications aimed at promoting individual student's responsibility, opportunities and social justice as citizen in practising their knowledge for a better earth.
\end{abstract}

Keywords: service-learning, social study

\section{INTRODUCTION}

Today, people are now faced with community risks. The population has indeed increased dramatically but is inversely proportional to the quality of the population. Environmental issues cannot be separated from the risk implications of this community. Indonesia is the largest archipelagic country in the world, with a vast area, and with a population in 2019 it is projected to be around 266.91 million according to data from an inter-census population survey [1]. With the high population, it is directly proportional to the amount of public consumption. Packaging materials that are still the choice of many people, due to price efficiency and durability, the community still uses plastic as a choice of packaging for their consumption materials. Indonesia is still ranked 133 out of 180 countries regarding the issue of overcoming environmental issues, even according to the earth day organization Indonesia is the second-highest plastic pollution country in the world after China. If this issue is not taken seriously then by 2050 , the number of fish will be less than plastic waste in the sea. Several regulations have been enacted by the government by working with companies such as the Indonesian Retail Entrepreneurs Association (Aprindo) to tackle this problem, for example, the Non-Free Plastic Bag (KPTG) policy in Jakarta, consumers are required to pay Rp.200, - if want to use plastic bags for shopping items. Inevitably, the regulation does not have a significant transformative impact in overcoming this.

The question about the role of education which ideally shapes people who have awareness and concern for their lives, fellow life and the continuity of this nature, is certainly inseparable from the phenomenon that is being faced globally. So we need to be more careful in giving a critique of the role of each classroom on this issue. Did the college escape from this role? what about the condition of the classroom conversation? Is there a solution that Education can contribute to opening up a solution to this issue? specifically, we need to ask also about the role of the science of social education. Class 2 social studies then questioned their role in creating a balanced society and supporting the advancement of civilization in the midst of this ongoing and globally experienced natural destruction situation. The stigma that social education cannot contribute, then every stigma must be changed.

How to offer contributions and activeness Social education in an era of environmental damage is important, because social education in particular civics education is an education that aims to form a society that has a sense of solidarity, is intelligent in democracy and is responsible for the social community and where they live. This issue is then raised to be discussed in this paper.

\section{THEORY}

For the general term citizenship education leads to classroom instruction, several reasons that can explain formal learning in the classroom do not have a significant impact on student learning outcomes, information about politics and government 
This indicates the fundamentality of civics education in the can be obtained from various channels, unlike mathematics or Pythagoreans that are not accessible easily from the general discussion table, but in class [2]. This makes citizenship learning need to think of ways to make the content become significant and urgent for students.

Global citizenship and civic engagement is increasingly a concern to be an essential goal of student learning outcomes [3]. Civics education not only teaches the knowledge of civics or the theory of how to be a good citizen but also understanding the civics skill to engage effectively and responsibly in public and democratic life [4]. Citizenship learning is assessed as learning that aims to form good citizens, directing the character of learners to become good citizens [5].

Environmental problems have become a multidimensional problem and certainly touch the realm of citizenship. One of the phenomena that will greatly affect the lives of citizens includes a significant increase in population, reduced availability of clean water, defaporation of forests and pollution of the environment as well as nuclear weapons [6]. Laws in Indonesia clearly regulate environmental protection and management, in law number 32, 2009. In fact there are still many environmental damage caused by human activities. According to Nursid Sumaatmadja, environmental principles one of the most important is the principle of sustainability, if this continuity is destroyed, then the environment will be destroyed too [13]. This shows the urgency of the role of citizens to maintain environmental resilience for present and future lives.

Grounded in positive youth development philosophy [10] we believe that our young citizens are the agent of transformation who need to be nurtured early before actually taking part in society and improve the quality of life in a community. Like John F. Kennedy once told "contribute part of your life to this country" and he believed that education is potential enough to connect young people's education to a broader public service mission [7]. One solution to educate and touch beyond the cognitive domain of students by giving students an opportunity to do service-learning. It has been enhanced civic responsibility and citizenship, personal and social skills through the combination of educational instruction and practice [14]. Shriver in [7] told to Jawaharlal Nehru in India that by permitting the volunteers to participate in India's development efforts, they would be giving the volunteers a chance to find themselves. Service-learning is often referred to as "experiential education" where learning takes position as actual learning compared to learning with traditional [8]. Service-learning programs are not only a prerequisite for obtaining grades, programs in syllabus, and activities fill vacancies, but through which students are given the opportunity to invest their knowledge and life for the formation of a sustainable environment and at the same time bring development in the character of students which is the main goal of education. availability of a democratic society, where there are citizens who are a personally responsible, participatory and justice-oriented citizen. The issue is, how civics education can show its escape from the stigma of theoretical learning and present more applicable and impactful to the society in this disruption era. A way out, by integrating service-learning into civics education program. Placing the issue concerned of is, the role of young citizens in creating environmental sustainability as a part of their civic responsibility in this disruption era, this is integrated into the topic of politics and national strategies contained in the civics syllabus.

\section{METHOD}

Qualitative research has being used for this research and case study was the approach for this. The research question for this case study was how the service-learning integrated into civics education developed as media for student's existence for a sustainable environment? The writer wants to investigate the characteristic of service-learning integrated into civics study at $\mathrm{XYZ}$ university as the media for student's existence as the agent of transformation especially in creating a sustainable environment. Qualitative research assumed as an appropriate or suitable way to find out the answer to this question research. The unstructured interview was used as tools, as Mulyana stated that unstructured or open-ended interview usually use to reveal life experience of the research subject [12] and this research proposed to explore how the student's think and feel toward the process of developed service-learning integrated to civics education. Using interview is more efficient than observation.

Descriptive qualitative, this method explains what can we do toward the interview result and gives logic explanations toward what the interview shows us. The data analysis was done by making interview transcripts first, then the data is read and studied carefully then the data is organized. After that the organized data is translated into units and synthesized. After the synthesis process, it will usually be seen a pattern that is the purpose of the analysis, then the emerging patterns are chosen which are the most important and answer the research focus [15]. From the process found the main themes that became the answer to the question of how service-learning was developed as a medium for the existence of students as agent of transformation in the community in order to realize environmental resilience in the Tangerang area. The questions in the interview are about How do you explain to others about service-learning activities in PKn learning? Tell us what SL you are working on in this semester, what personal experience you have, is there a soft skill that you just realized you have after implementing servicelearning. How can service-learning be a medium for you to become an agent of transformation for environmental security in your area. 


\section{RESULTS AND DISCUSSION}

Service-learning held at XYZ University is a culminating activity held in the last two weeks before the semester ends. The stages that must be taken by students before implementing service-learning can be seen in the following flow diagram. There are 15 steps taken by students, including filling out the registration form, choosing a location (can take from a university partner or from outside). Consult with the lecturer about the form of the event and the theme of the activity. Students are asked to take a survey cover letter. After that the survey was conducted. After the survey was carried out, students began compiling proposals and endorsing proposals. After the proposal has been approved, then service-learning is held. After the implementation of service-learning, students are asked to take several children for feedback from the activities that have been carried out. Students also request feedback from the leadership or operations of the institution where students carry out servicelearning. After the implementation of service-learning, students write reports on the results of their service-learning. In the report students are asked to write self-reflection about the things they learned from implementing service-learning. Self-reflection of the implementation of service-learning becomes a practical guideline in interpreting the meaning of service-learning for each student. In personal writing about what they get from service-learning activities can enrich the knowledge of the function of service-learning as a medium for the existence of students, because in presentations, the chances are that students are not brave enough to express various things that are written in their minds, compared to if written on paper.

\section{TAHAPAN PELAKSANAAN}

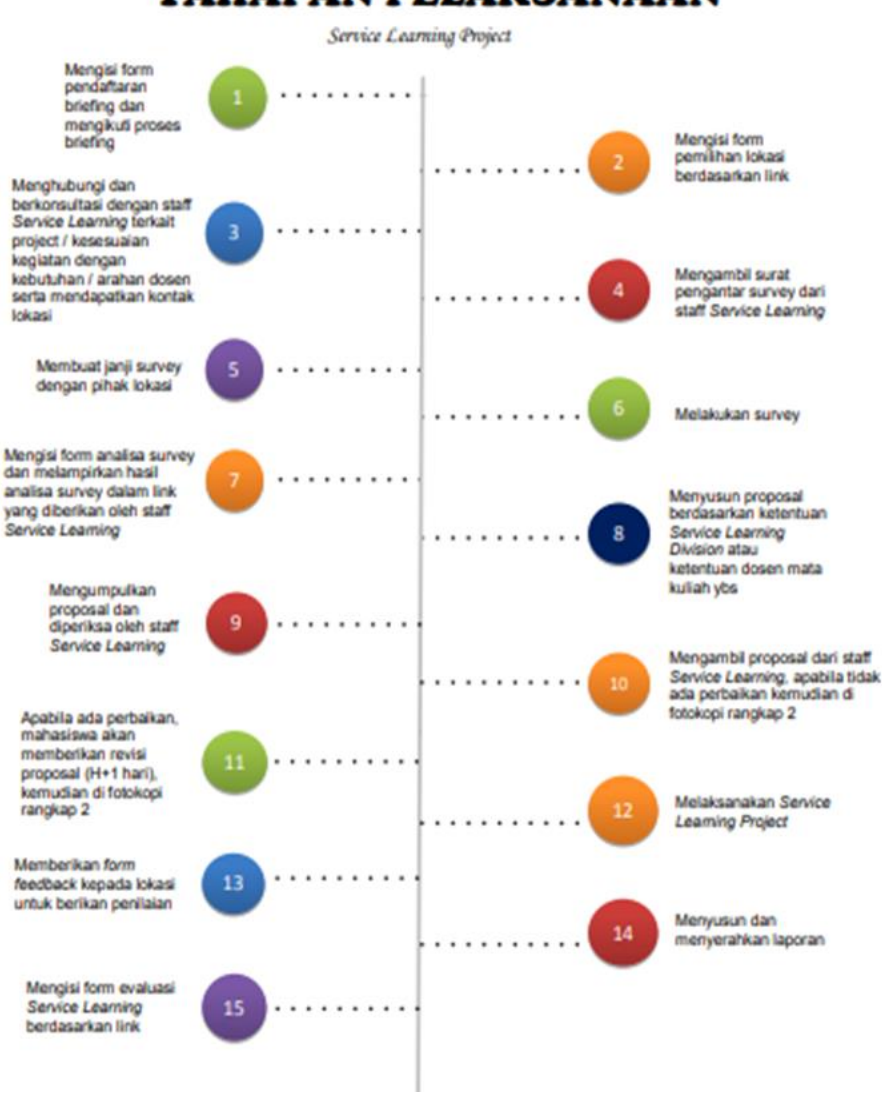

Fig. 1. The steps of Service Learning in the University

\section{A. Views of Service Learning}

It seems that the views of students about this activity cannot be described by negative sentences because based on the results of interviews and self-reflection students both describe the positive views obtained by students from this activity. Students who had previously considered service-learning activities as charitable activities had changed, because through this activity students also had the opportunity to share knowledge with children in their surrounding environment. Service-learning is a medium for students to participate significantly in the community. Student insight is increasingly open that this environmental issue is really something that needs a solution as soon as possible. Service-learning is also a medium for students to get positive feelings, more appreciated. Students feel the response from children at the visit location arouses feelings of being more valued and expected. This positive feeling is very good for students in motivating them to become better people. Students also claim that they feel increasingly responsible for their role as citizens. 


\section{B. Soft Skills of Students Who Are Built}

In the prologue part of the book written by the DirectorGeneral of Learning and Student Affairs, RISTEK DIKTI, it was written that general education accommodates the transition process to education and teaching that equips students with reasoning, analytical, communication skills, the ability to work in groups. Service-learning conducted at XYZ University is conducted after the end of the citizenship course as a form of concrete action after learning various concepts in the class. This course is carried out under the general education unit or what is called liberal arts at this university. From the results of interviews and reading personal reflections of students, it was found that students found themselves increasingly aware of the abilities and skills they possessed. For example in communication skills. Initially students did not realize that they had talent in public speaking, but after participating in this activity, they realized the other abilities they had. Because at the time of the event, it was possible for all the activities that had been arranged with the speakers and officers each to change for various reasonable reasons so that they had to replace colleagues who were unable to guide the event or negotiate with the institution leaders. The ability to communicate with others is the government's target for college graduates after participating in general education programs.

From the interviews, the students also said that they realized that working in groups was difficult. In preparing service learning they experience many internal debates in groups, for example regarding location, forms of activities that support the topic, division of labour to formulate fund planning. They must learn to suppress their respective egos, control emotions, communicate in polite and orderly language. Everything is aimed at keeping the group solid and the purpose of the event well implemented. The ability to work in groups is also a skill that is expected to grow in students as a young generation of the nation.

Service-learning is a place to learn real and direct leadership. In contrast to learning various theories of leadership learned in class, students find that the leadership they apply due to the existence of service-learning feels more real, even not discussed in various books about leadership itself. As leaders they must learn to apply critical thinking, the ability to decide quickly and precisely. Such abilities are not learned in classroom learning sessions, students get them from various processes carried out in service-learning.

\section{CONCLUSION}

Seeing the condition of the earth which is getting worse due to human activities, citizens are considered necessary to take action immediately. The most effective way is through education because education has a primary goal as a medium to transform human behaviour and character. Unfortunate facts about the education process, especially social studies, have not sufficiently accommodated the formation of human characters who care and love the earth where they live and work. Many think that social science education including citizenship does not need to take part. But at XYZ university they applied citizenship learning and closed it with the implementation of servicelearning. They require students to do service learning by going directly to the community and becoming a solution to any problems faced by society. In this short semester they chose to do service learning with a focus on environmental issues. This is interesting because these students show their concern about environmental issues through service-learning. They prove that social science can contribute to the progress and positive development and resilience of the environment for the survival of this earth. Service-learning is a medium for students to express their role as agents of transformation, but all this can happen with the supervision and full direction of the lecturers in their respective subjects, thus simple actions taken by students for a better earth.

\section{REFERENCES}

[1] BPS (2018). Proyeksi Penduduk Indonesia 2015-2045 Hasil Supas 2015 [e-book]. Diakses pada tanggal 21 Juni dari https://www.bps.go.id/publication/2018/10/19/78d24d9020026ad95c6b5 965/proyeksi-penduduk-indonesia-2015-2045-hasil-supas-2015.html)

[2] Campbell, 2019. What Social Scientists Have Learned About Civic Education: A Review of the Literature. Peabody Journal of Education. 2

[3] Bish G, Lommel J 2016. Enhancing Global Service Learning with Partnerships as an Engagement Strategy for Christian Higher Education. Christian Higher Education. 15287

[4] Mahadir N, Piang T, Jamil Z 2019. Promoting Good Citizens through Service-Learning Engagement in Multi-Ethnic Malaysia. International Journal of Academic Research in Business and Social Sciences. 9940

[5] Fitriasari S, Riyan Y. 2017 Model PEmbelajaran Pendidikan Pancasila dan Kewarganegaraan untuk menumbuhakna Karakter Peduli Lingkungan Hidup Siswa. Prosiding KOnferensi Nasional Kewarganegaraan III. 167

[6] Feriandi, Y. 2018. Upaya Perlindungan Lingkungan Perspektif Konstitusi dan Pendidikan KEwarganegaraan. Jurnal Pancasila dan Kewarganegaraan. 328

[7] Busch, D., 2018. Service Learning: The Peace Corps, American Higher Education, and the Limits of Modernist Ideas of Developmenr and Citizanship. History of Education Quarterly. 58475

[8] Allin, S. 2017. Higher Education Student Learning Beyond the Classroom: Findings from A Community Music Service Learning Project in Rural South Africa. Music Education Research. 19232

[9] daniel, A 2015. Civics Education for Sustainable Development and Its Consequences for German Civic Education Didactics and Curricula of Higher Education. Discourse and Communication for Sustainable Education. 630

[10] Lerner, Richard M.Wang, Jun /Champine, Robey B. Warren, Daniel J.A. Erickson, Karl. 2014. Civic Engagement Development - Results from Longitudinal Studies.

[11] Hart S, Wandeler C. 2019. The Impact of Action Civics Service-Learning on Eight Graade Students' Civic Outcomes. International Journal of Research on Service-Learning and Community Engagement. 61

[12] Mulyana, Deddy. 2004. Metodologi Penelitian Kualitatif. Bandung: PT Remaja Rosdakarya 
PRESS

[13] Prodjodikoro, Wirjono.1981. Asas-asas Hukum Pidana di Indonesia, cet.3, PT Eresco, Jakarta-Bandung

[14] Andrew Furco, Susan Root. 2014. Research Demonstrates the Value of Service Learning.

[15] Sugiyono. 2017. Metode Penelitian Kuantitatif, Kualitatif, dan R\&D. Bandung: Alfabeta 